University of Nebraska - Lincoln

DigitalCommons@University of Nebraska - Lincoln

USDA Forest Service / UNL Faculty Publications U.S. Department of Agriculture: Forest Service --

National Agroforestry Center

1996

Identification and characterization of a RAPD-PCR marker for distinguishing Asian and North American gypsy moths

\author{
K.J. Garner \\ USDA Forest Service
}

Follow this and additional works at: https://digitalcommons.unl.edu/usdafsfacpub

Part of the Forest Sciences Commons

Garner, K.J., "Identification and characterization of a RAPD-PCR marker for distinguishing Asian and North American gypsy moths" (1996). USDA Forest Service / UNL Faculty Publications. 127.

https://digitalcommons.unl.edu/usdafsfacpub/127

This Article is brought to you for free and open access by the U.S. Department of Agriculture: Forest Service -National Agroforestry Center at DigitalCommons@University of Nebraska - Lincoln. It has been accepted for inclusion in USDA Forest Service / UNL Faculty Publications by an authorized administrator of DigitalCommons@University of Nebraska - Lincoln. 


\section{Identification and characterization of a RAPD-PCR marker for distinguishing Asian and North American gypsy moths}

\author{
K. J. Garner and J. M. Slavicek \\ USDA Forest Service, Northeastern Forest Experiment \\ Station, Delaware, Ohio, USA
}

\begin{abstract}
The recent introduction of the Asian gypsy moth (Lymantria dispar L.) into North America has necessitated the development of genetic markers to distinguish Asian moths from the established North American population, which originated in Europe. We used RAPD-PCR to identify a DNA length polymorphism that is diagnostic for the two moth strains. The polymorphism maps to an autosomal locus with codominant Mendelian inheritance. DNA sequence analyses of the Asian and North American forms enabled development of locus-specific primers so that this marker, designated FS-1, will be useful for strain identification under varying conditions in different laboratories.
\end{abstract}

Keywords: gypsy moth, Lymantria dispar, RAPD-PCR, sequence-characterized amplified region (SCAR).

\section{Introduction}

Gypsy moths originating in Europe were accidentally released in Massachusetts in 1869 (Forbush \& Fernald, 1896) and have spread throughout New England. Adjacent areas of Canada have also been affected. The leading edge of the infestation is now in Maine, Michigan, Ohio, North Carolina, Virginia, and West Virginia, and isolated outbreaks have been found in almost every state in continental USA (USDA Forest Service, 1995). Although efforts are being made to slow the spread of the infestation, and to reduce defoliation at outbreak sites, the North American gypsy moth is considered to be too well established to eradicate.

Received 8 August 1995; accepted 9 October 1995. Correspondence: $\mathrm{Dr}$ James M. Slavicek, USDA Forest Service, Northeastern Forest Experiment Station, 359 Main Road, Delaware, OH 43015, USA.
In 1991 gypsy moths originating in Asia were discovered on ships attempting to enter ports in the Pacific Northwest (Gibbons, 1992; Wood, 1994; Mudge et al., 1994). The Asian gypsy moth differs from the North American population in having a larger range of preferred host trees, including economically-important conifers. In addition, the Asian strain may be capable of more rapid migration than the North American strain, because the Asian females are capable of flight (Wallner et al., 1994), whereas North American females are flightless. For these reasons, the decision has been made to attempt to eradicate known Asian infestations in the United States.

The native range of the gypsy moth extends across Eurasia and North Africa. The highest levels of morphological and developmental variation have been described in the far eastern regions of the range, especially Japan (Goldschmidt, 1940; Harrison et al., 1983), and it is possible that the species arose there and spread westward. Similar patterns of variation have been found using isozyme (Harrison et al., 1983) and mitochondrial restriction site polymorphism (Bogdanowicz et al., 1993) analyses.

An extensive study by Goldschmidt (1940) showed that some Asian/European crosses resulted in partial or full sex reversals, although Clarke \& Ford (1980) were unable to reproduce these findings to the same extent. A recent cytogenetic study has found evidence of abnormal meiosis in testes of Asian/North American F1 hybrid males (Krider \& Shields, 1994). Nevertheless, moths from far eastern Asia and Europe are frequently capable of hybridization under laboratory conditions (Keena, 1994a, b). When these hybrids are evaluated for such traits as diapause chill requirements, larval colour, adult size, and female flight capability, the hybrids are usually intermediate between the Asian and North American forms, or else tend to more closely resemble the Asian parent. Because the characteristics of further generations of Asian/North American hybrids outside of the laboratory cannot be predicted, the presence of hybrids in North America is a cause for concern. 
Gypsy moth populations are monitored by trapping male adults in pheromone-baited sticky traps. Morphological differences between Asian and North American moths are slight and identification of Asian moths can be difficult, especially if the specimen is damaged. Asian and North American larvae possess differences in body coloration (Keena, 1994a, b) and can be identified on the basis of head capsule coloration (Wallner et al., 1995). However, the larvae are not subject to pheromone trapping at low population densities, as are the male adults. In order to identify trapped male moths, DNA markers that can be used on poorly-preserved samples or tissue fragments have been sought. Mitochondrial DNA markers for the Asian and North American strains are presently being used to identify trapped moths (Bogdanowicz et al., 1993). However, because of the maternal inheritance of mitochondrial DNA, these markers identify only the genotype of the maternal parent in the case of a hybrid moth. Therefore additional markers representing nuclear DNA have been sought.

Because little genetic information is available for the gypsy moth, we used random amplification of polymorphic DNA by the polymerase chain reaction (RAPD-PCR) to look for fixed DNA polymorphisms between the genomes of the two moth strains. RAPD$\mathrm{PCR}$ is a technique that uses short oligonucleotide primers and non-stringent reaction conditions to amplify multiple DNA fragments from a genomic DNA sample (Williams et al., 1991). The amplified DNA fragments are frequently polymorphic and can be used as markers for genetic mapping and as indicators for species, strains or populations of organisms under circumstances where the markers are determined to be heritable traits. RAPD-PCR markers have been used to distinguish strains of bacteria (Scieux et al., 1993), populations of nematodes (Folkertsma et al., 1994) and species and populations of insects (Edwards \& Hoy, 1993; Gawel \& Bartlett, 1993; Puterka et al., 1993; Roehrdanz et al., 1993; Favia et al., 1994). RAPD-PCR has also been used to assess genetic variability in German gypsy moths, although markers for regional populations have not been defined (Graser et al., 1995).

We tested 222 decanucleotide primers in search of diagnostic markers for Asian and North American gypsy moths. In general, the two strains are similar when analysed using this method; however, one DNA length polymorphism has been found that distinguishes the two strains with a high degree of accuracy. We cloned and sequenced the amplified diagnostic DNA regions in both Asian and North American moths and developed locus-specific primers that successfully amplify this region in crude DNA extracts of moth tissue. Markers of this type have been referred to as 'sequence-characterized amplified regions' or SCARs (Paran \& Michelmore, 1993). This marker should be useful in the identification of trapped adult insect specimens as well as other life stages including eggs.

\section{Results}

\section{Screening of RAPD PCR primers}

Decanucleotide primers were initially tested on a small set of gypsy moth DNA samples in order to find primers that amplified markers specific for one or the other population. In general it appears that the two populations are not well differentiated genetically, because most primers amplify bands common to both populations.

Twenty primers were selected for a band-sharing analysis of fifteen Asian and nine North American moths. A sample result is shown in Fig. 1. A total of 322 RAPD bands were scored, including all but very weak ones. Of these, twenty-four were present in all individuals, 168 were present in one or more individuals of both strains, and 128 were found in some but not all individuals of one strain. Only two fragments were seen in all individuals of one (North American) but not the other strain within this primer set. Pairwise distances between individuals were calculated by dividing the number of differing bands by the total number of bands scored. The average pairwise distance within the Asian population is 0.26 ; the average distance between Asian and North American moths is 0.27 ; and the average distance within the North American population is 0.16 .

Of 222 RAPD-PCR primers tested, seventeen $(7.7 \%)$ initially appeared to amplify Asian or North American diagnostic fragments. However, ten failed to be strainspecific when larger numbers of samples were tested (data not shown). Seven of the remaining marker fragments were cloned and sequenced and locusspecific primers were selected. However, four of these primer sets failed to amplify the expected band, and two amplified the same band in both Asian and North American samples (data not shown).

One primer, OPD-02, consistently amplified an approximately 700 basepair fragment in Asian moths and an approximately 590 basepair fragment in North American moths (Fig. 2A). This primer also amplified other fragments; however, these were not diagnostic for either strain.

\section{Characterization of the diagnostic fragments amplified by primer OPD-02}

In order to develop locus-specific primers, the Asian 


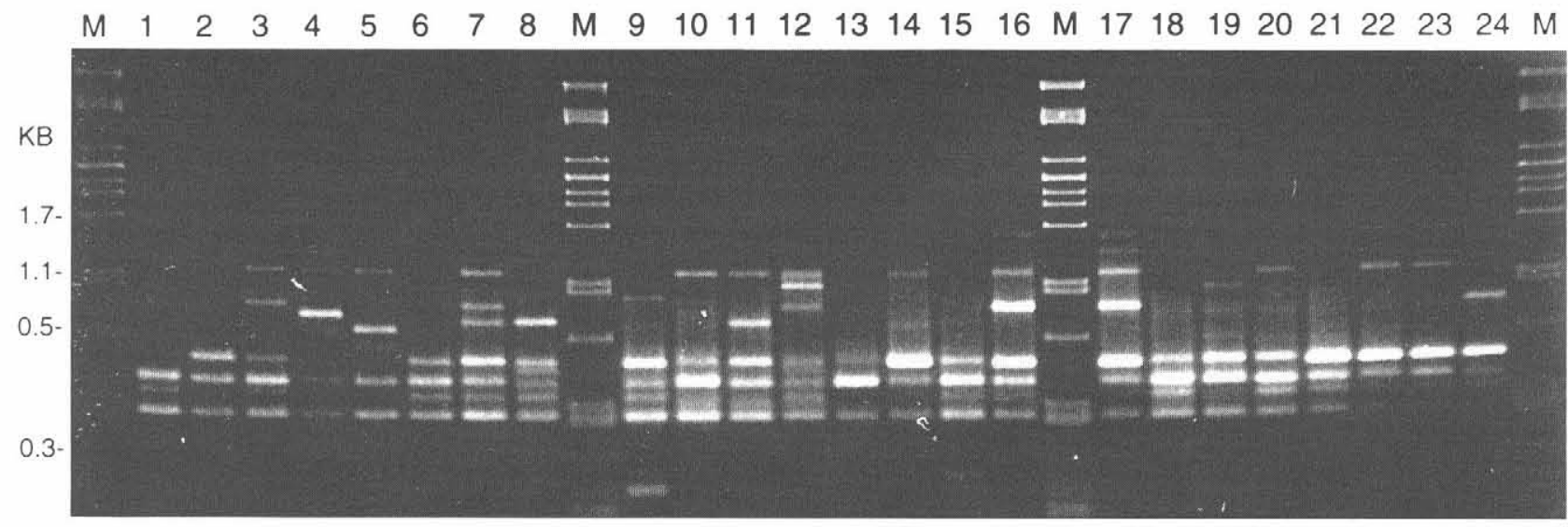

Figure 1. Example of RAPD-PCR band analysis. RAPD-PCR products generated from Asian and North American gypsy moth DNA using primer UBC 108. Lanes 1-15, Asian moths from eastern Russia. Lanes 16-24, North American moths from NJ (16 and 17), PA (18), MA (19 and 20), WV (21), OH (22), and MI (23 and 24). Lanes labelled ' $M$ ' contain a molecular weight marker (lambda phage DNA digested with Psti).
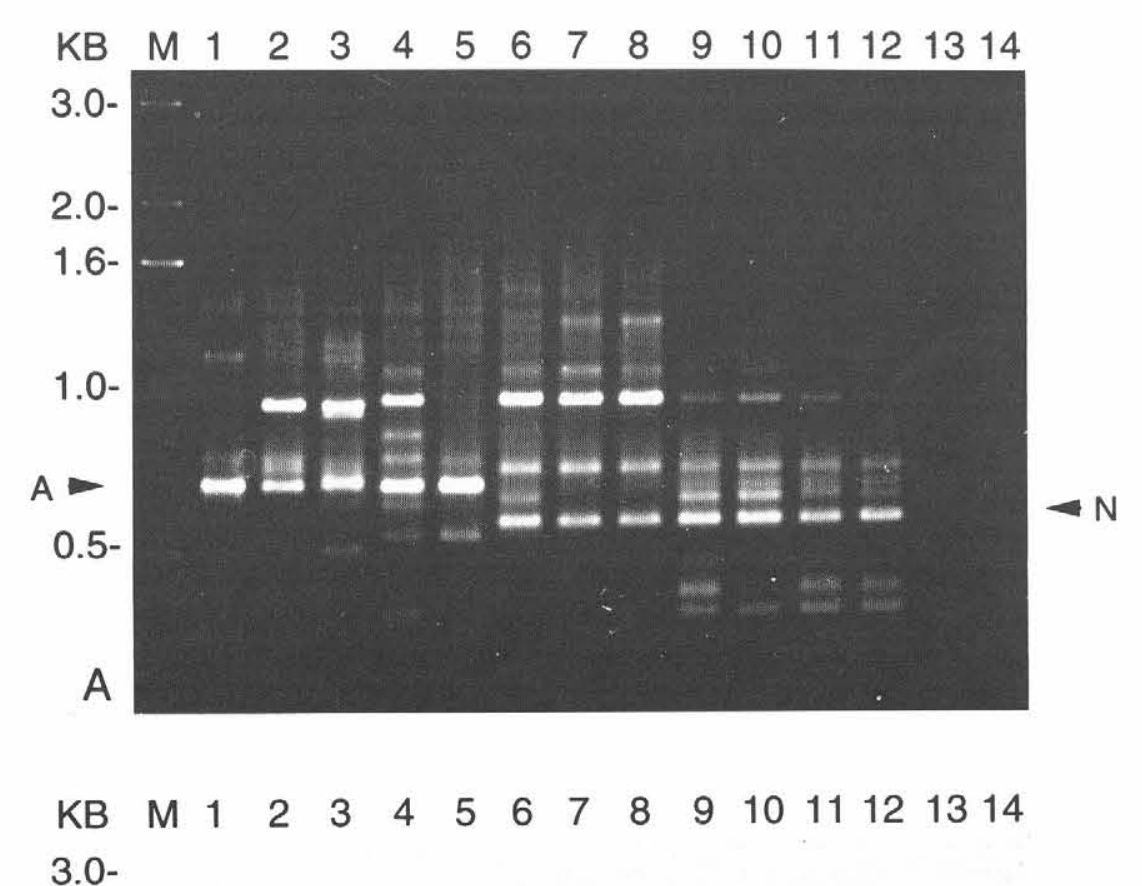

2.0-

$1.6-$

Figure 2. Detection of gypsy moth strain-specific markers using primer OPD-02. (A) RAPD-PCR products generated from Asian and North American gypsy moth DNA using primer OPD-02. Lanes 1-5, Asian moth DNA; lanes 6-12, North American moth DNA; lanes 13 and 14, DNA-minus controls; lane M, molecular weight marker ( $1 \mathrm{~kb}$ ladder, Gibco BRL). Asian and North American marker bands are indicated by arrows. (B) Hybridization of cloned OPD-02 700 DNA to a Southern blot of the gel shown in (A). Asian and North American marker bands are indicated by arrows.

\section{$1.0-$}

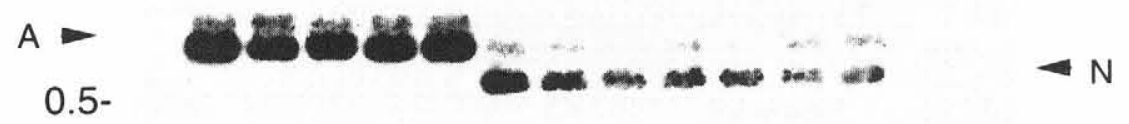




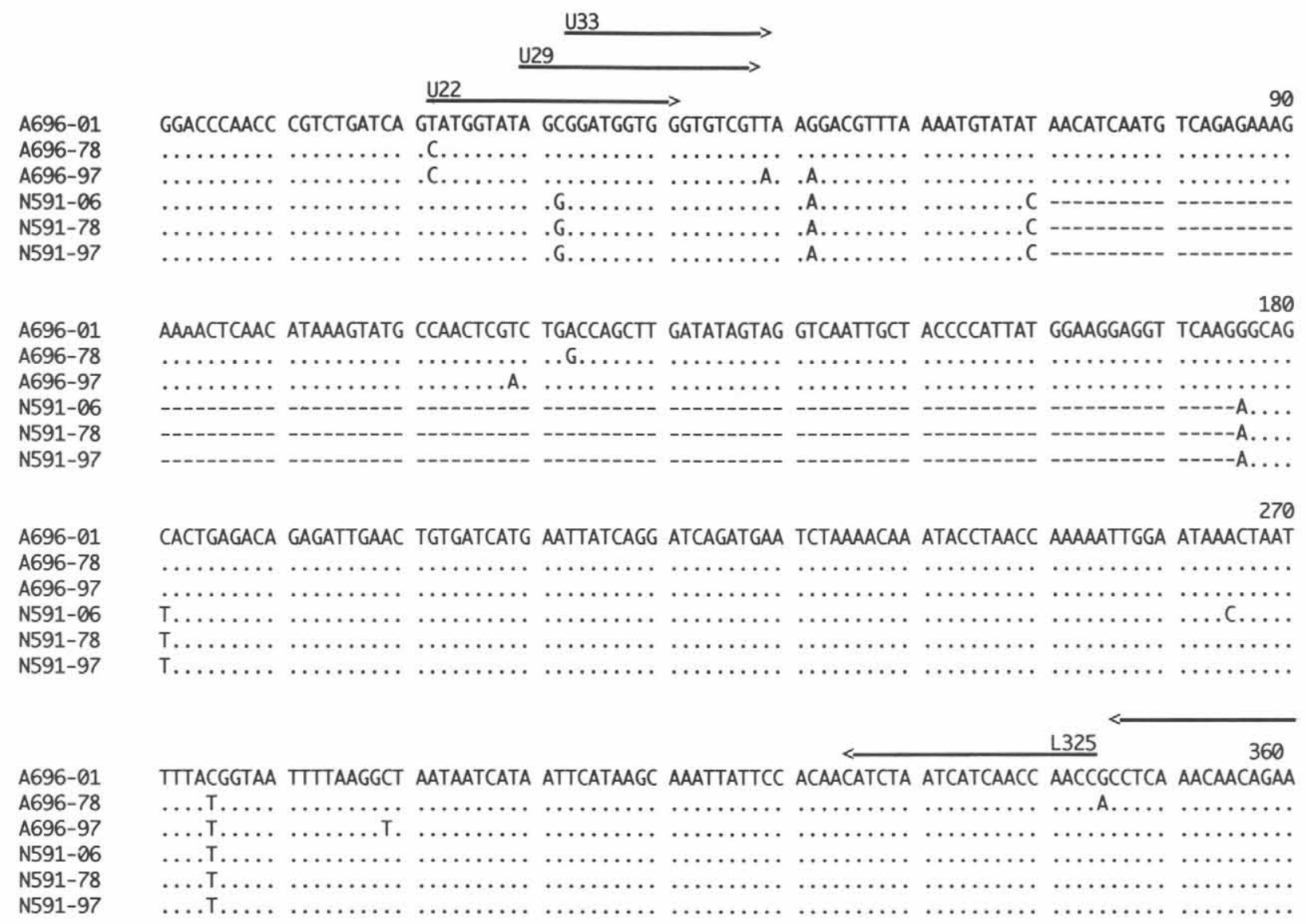

$\underline{\mathrm{L} 346}$

A696-01 A696-78 A696-97 N591-06 N591-78 N591-97

A696-01 A696-78 A696-97 N591-06 N591-78 N591-97

A696-01 A696-78 A696-97 N591-06 N591-78 N591-97

A696-01 A696-78 A696-97 N591-06 N591-78 N591-97
L374

450 CAAATGAGCA ACACGTCGAT GTCCTCTCCG GAATGACAAT GATTATTGTA ACAGCCTCAT AAACCGGCAT TATTGTGAGC GCACTGTATT

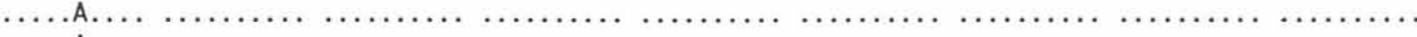

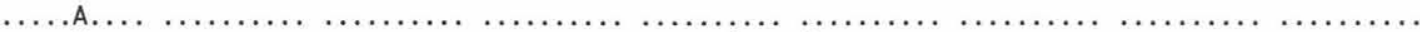

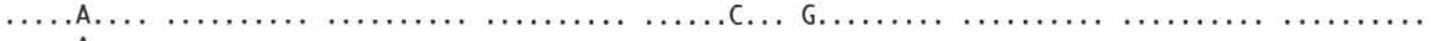

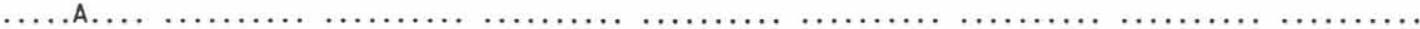

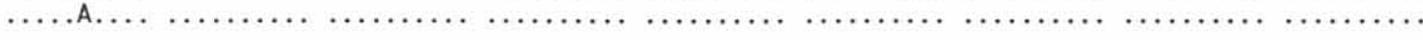

540 TATACGCCAT AGCAATTATC GGTCGTAACT GCCGCATCGA TCTTCGTCGA TAATTGCCTT GTGAAACATG AGTTATTGTT CCATCTGAAC

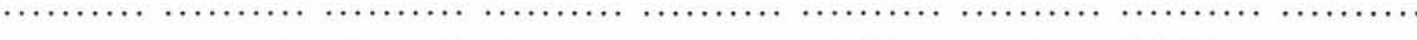

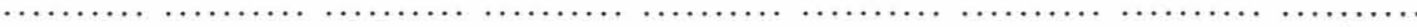

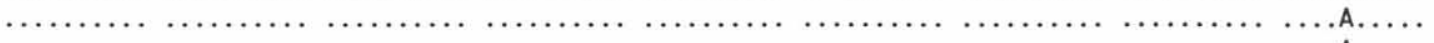

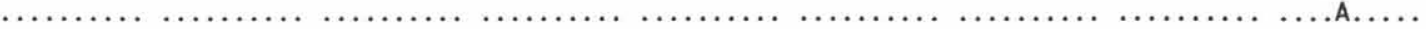

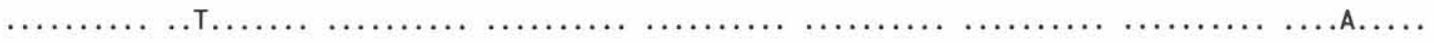

TAATTAGTGT ATGTITTAG GITAAGGGG ACATITGAA GTTATACTAC TTCTGACACT TTAGGGAAAA AACATCATCG GGCCGACCAC

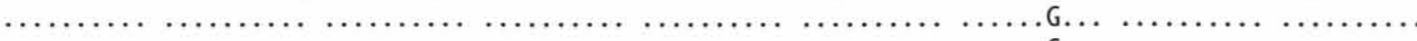

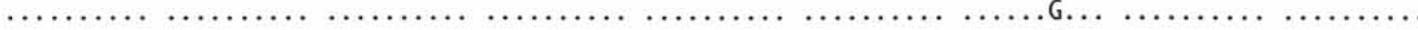

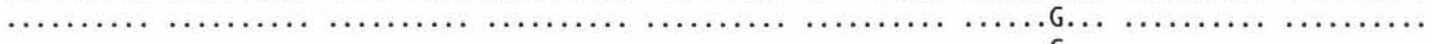

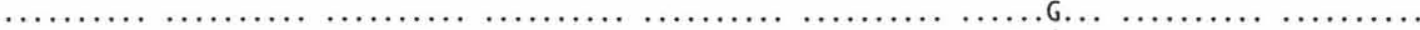

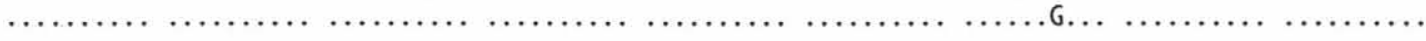

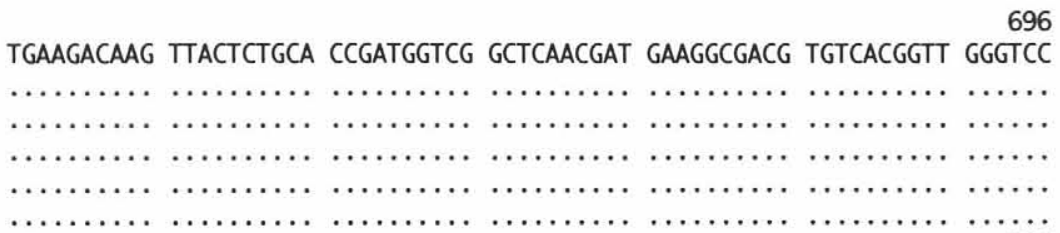


Figure 4. Amplification products obtained using locus-specific primers U22 and L346. Lanes $1-6$, Asian moths; lanes 7-10, hybrids; lanes 11-16, North American moths. Lane M, $1 \mathrm{~kb}$ ladder. Asian and North American marker bands are indicated by arrows.

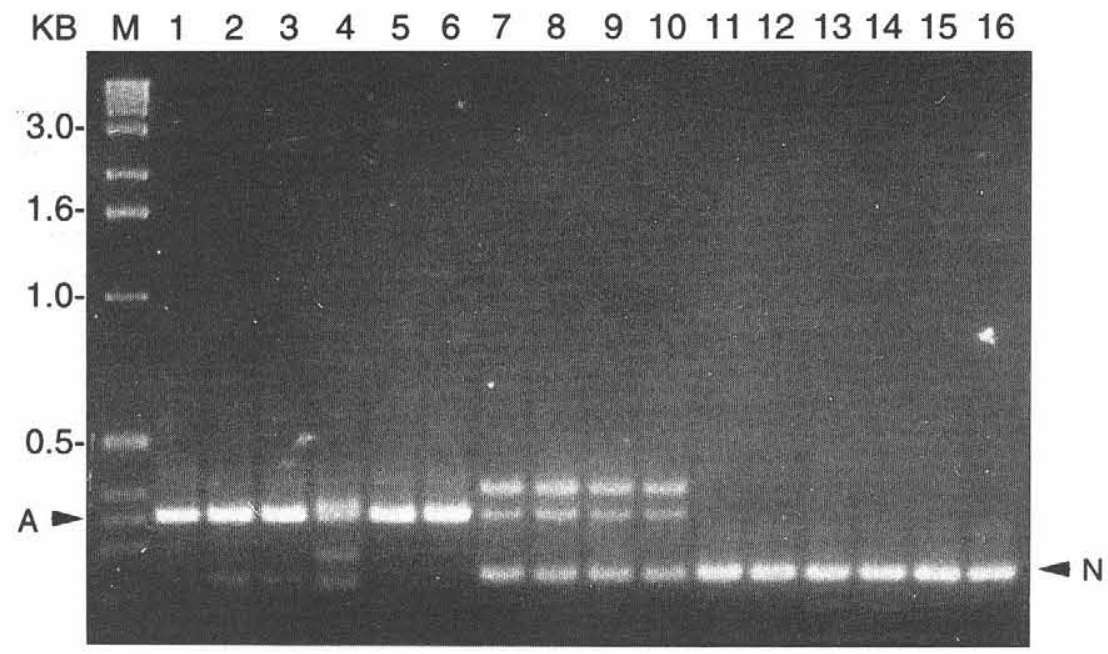

and North American fragments were cloned and sequenced. To confirm the identity of the clones, plasmid insert DNA from clones of both fragments was radioactively labelled and hybridized separately to a blot of RAPD PCR-amplified DNA. Both clones hybridized to both the 700 and 590 basepair regions of the blot, indicating shared sequences between the two fragments (Fig. 2B). Sequences of both fragments were each determined from three individuals (Fig. 3 ). The actual sizes of the Asian and North American fragments are 696 and 591 basepairs respectively, and they have been designated OPD- $02_{696}$ and OPD$02_{591}$, respectively. Sequence comparisons of the fragments show that the sequences are nearly identical $(99 \%)$ except that the Asian fragment has a 105 basepair region that is missing in the North American fragment. There are also five nucleotide positions (homologous site numbers 32, 70, 176, 181 and 535) showing fixed differences between Asian and North American strains. It is not known whether the 105 basepair region was inserted in the Asian or deleted from the North American allele. It does not display flanking repeats that might be associated with a transposable element. Neither the Asian nor the North American fragment sequence contains any long open reading frames. Searches of the GenBank databases with the DNA sequences and with translations of the short open reading frames have not yielded significant matches.

\section{Selection of locus-specific diagnostic primers}

Longer primers (17-20 bases) were selected from DNA sequence flanking the insertion/deletion region in areas with few or no polymorphic bases between the Asian and North American sequences. These primers were used to analyse gypsy moth DNA samples of known geographic origin. As expected, with primers U22 and L346 a fragment 345 basepairs in length is amplified in Asian moths and one 240 basepairs in length is amplified in North American moths (Fig. 4). In hybrids, both the Asian and North American forms are seen, as well as an additional, more slowly-migrating band which is a heteroduplex formed during the annealing stage of the amplification process. This heteroduplex band was formed in the absence of Taq DNA polymerase by mixing pure Asian and North American amplified DNA and subjecting the mixture to a PCR amplification cycle (data not shown).

Additional weak bands are sometimes seen when using the locus-specific primers (Fig. 4, lanes 2, 3 and 4). In these lanes a fragment is seen that is similar in size to the North American fragment, which might lead to misidentification of these Asian samples as hybrids. However, in these lanes the lack of the heteroduplex band indicates that the samples are not true hybrids. Comparison of amplified products from DNA samples being tested with those from known standard DNAs usually allows an accurate identification of specimens.

Figure 3. Alignment of Asian and North American marker band sequences. A696-01 is from a far-east Russian moth; N591-06 is from a New Jersey Standard Strain North American moth; A696-78 and N591-78 are from a North American moth from Ashtabula Co., Ohio; and A696-97 and N591-97 are from a Russian/MA hybrid moth. Matches with A696-01 are indicated by dots, deletions are indicated by hyphens. Locations of locus-specific primer sequences are indicated by arrows. 
With some samples, differing results are seen with the locus-specific primers and OPD-02. These differences are probably caused by nucleotide polymorphisms at the primer binding sites. The primers U22 and L346 were actually the third set designed. The first primers, U33 and L325, were designed based on the first two sequences determined, A696-01 and N591-06. In one hybrid individual these locus-specific primers failed to amplify an Asian fragment even though one was seen when the same DNA was amplified using OPD-02. The OPD-02 $2_{696}$ fragment from this individual (A696-97) was cloned and sequenced and the sequence was compared with the original OPD-02 696 sequence. A T-A substitution at site number 49 was seen at the U33 primer binding site (see Fig. 3, sequence A696-97). Initially, a second nucleotide change was seen at the L325 primer binding site, but upon sequence analysis of additional clones, that mutation proved to be a Taq polymerase error. A second locus-specific primer set, U29 and L374, was selected based on this additional sequence information, but these primers failed to amplify the expected bands. A third set, U22 and L346, was selected and this set seems to amplify most variants, although more testing is needed. The diagnostic fragments amplified by both RAPD-PCR primer OPD-02 and by the specific primers have been designated as the FS-1 marker.

Assessment of the accuracy of the FS-1 marker on samples of known origins

Table 1 shows the results of amplification of 370 moth samples with OPD-02 or the specific primer sets U22 and L346, or U33 and L325. To date these primers have been used to analyse 116 Asian moth DNA samples, of which 114 have the Asian form of the marker $(98 \%)$ and two have both forms. The two individuals that show the hybrid pattern are from central Russia (Bellyk, in Krasnoyarsk Territory) and the moths in this region may have an increased occurrence of the so-called North American form due to a natural east/west cline in allele frequencies. When only samples originating in far eastern Asia are counted, $100 \%$ type correctly as Asians. 154 North American samples were analysed, with 148 having the North American form (96\%) and six typing as hybrids. $100 \mathrm{~F}_{1}$ hybrid moths were analysed. Of these, ninetytwo type as hybrids (92\%), four type as Asians and four type as North Americans. The four hybrid individuals that type as North Americans have an Asian parent from central rather than far eastern Russia. Based on samples of far eastern Asian parentage, the FS-1 marker has an accuracy rate of $96 \%$ for detecting hybrids.
Table 1. Results of analyses of gypsy moth samples from known locations with FS-1 marker. Samples were analysed with RAPD primer OPD02 or specific primers U33 and L325, or U22 and L346. Sample origins (numbers tested): $\mathrm{CH}$, China: Beijing (4), Hubei, (5) Liaoning (5) and Shandong (5). JA, Japan: Hokkaido (9), Kashiwada (2), Kukisaki (1), Namiki (2) and Sakuragaoka (1). RB, Bellyk, Central Russia. RM, Mineralni, far-eastern Russia. Ship, ships intercepted on route from far-eastern Russia. North American samples are indicated by state of origin except that NJ refers to the New Jersey Standard Strain, a laboratory strain. Hybrid descriptions list the maternal strain first.

\begin{tabular}{|c|c|c|c|}
\hline & $\begin{array}{l}\text { Asian } \\
\text { form }\end{array}$ & $\begin{array}{c}\text { Hybrid } \\
\text { (both forms) }\end{array}$ & $\begin{array}{c}\text { North } \\
\text { American } \\
\text { form }\end{array}$ \\
\hline \multicolumn{4}{|l|}{ Asian } \\
\hline $\mathrm{CH}$ & 19 & & \\
\hline JA & 15 & & \\
\hline RB & 7 & 2 & \\
\hline $\mathrm{RM}$ & 45 & & \\
\hline Ship & 28 & & \\
\hline Total & 114 & 2 & \\
\hline \multicolumn{4}{|l|}{ Hybrid } \\
\hline $\mathrm{NJ} \times \mathrm{JA}$ & & 12 & \\
\hline$J A \times N J$ & & 11 & \\
\hline$M A \times R M$ & 3 & 10 & \\
\hline $\mathrm{RM} \times \mathrm{MA}$ & 1 & 5 & \\
\hline$R B \times R M$ & & 4 & 4 \\
\hline $\mathrm{NC} \times \mathrm{RM}$ & & 27 & \\
\hline $\mathrm{RM} \times \mathrm{NC}$ & & 23 & \\
\hline Total & 4 & 92 & 4 \\
\hline \multicolumn{4}{|c|}{ North American } \\
\hline $\mathrm{CT}$ & & & 10 \\
\hline MA & & 1 & 30 \\
\hline $\mathrm{MI}$ & & & 16 \\
\hline NC & & & 25 \\
\hline NJSS & & & 13 \\
\hline $\mathrm{OH}$ & & 4 & 17 \\
\hline PA & & & 12 \\
\hline WV & & 1 & 25 \\
\hline Total & & 6 & 148 \\
\hline
\end{tabular}

Efficacy of markers used on DNA from samples at various developmental stages

The RAPD primer OPD-02 and the locus-specific primers amplify the expected DNA bands from DNA prepared from adults, pupae, larvae and diapausestage eggs. The diapause-stage eggs contain welldeveloped embryos. The samples described in Table 1 included 59 eggs, 102 larvae, nine pupae, and the remainder were adults (132 males and 68 females). We have seen no indication that the FS-1 primers amplify sequences that are specific to the stage of development.

\section{Inheritance of markers}

Parental, $F_{1}, F_{2}$ and backcross moth DNA samples were tested to investigate the mode of inheritance of 
Table 2. Results of $F_{2}$ and backcross gypsy moth samples analysed with FS-1. A, Asian form; $\mathrm{H}$, both Asian and North American form; N, North American form. Hybrid descriptions list the maternal type first.

\begin{tabular}{lll}
\hline & Expected & Observed \\
\hline $\begin{array}{l}\text { Parental strains } \\
\quad \text { Russian (R) }\end{array}$ & $5 \mathrm{~A}$ & $5 \mathrm{~A}$ \\
$\quad$ North Carolina (NC) & $5 \mathrm{~N}$ & $5 \mathrm{~N}$ \\
F $_{1}$ hybrids & & \\
$\quad$ NC by Russian (NCR) & $5 \mathrm{H}$ & $5 \mathrm{H}$ \\
$\quad$ Russian by NC (RNC) & $5 \mathrm{H}$ & $5 \mathrm{H}$ \\
$\begin{array}{l}\text { F hybrids } \\
\text { RNC } \times \text { RNC }\end{array}$ & $5 \mathrm{~A}, 10 \mathrm{H}, 5 \mathrm{~N}$ & $4 \mathrm{~A}, 9 \mathrm{H}, 7 \mathrm{~N}$ \\
$\quad$ NCR $\times$ NCR & $5 \mathrm{~A}, 10 \mathrm{H}, 5 \mathrm{~N}$ & $4 \mathrm{~A}, 13 \mathrm{H}, 3 \mathrm{~N}$ \\
Backcross hybrids & & \\
$\quad$ NCR $\times$ NC & $9.5 \mathrm{~N}, 9.5 \mathrm{H}$ & $9 \mathrm{~N}, 10 \mathrm{H}$ \\
RNC $\times$ R & $10 \mathrm{~A}, 10 \mathrm{H}$ & $11 \mathrm{~A}, 9 \mathrm{H}$ \\
\hline
\end{tabular}

the Asian and North American markers. The results are shown in Table 2. All $F_{1}$ hybrids typed correctly, having both the Asian and North American fragments. The results with two sets of $F_{2}$ hybrids were also very close to the expected ratios of 1:2:1 for Asians, hybrids and North Americans, respectively. One set had four Asian, nine hybrid and seven North American types and the other had four Asian, thirteen hybrids and

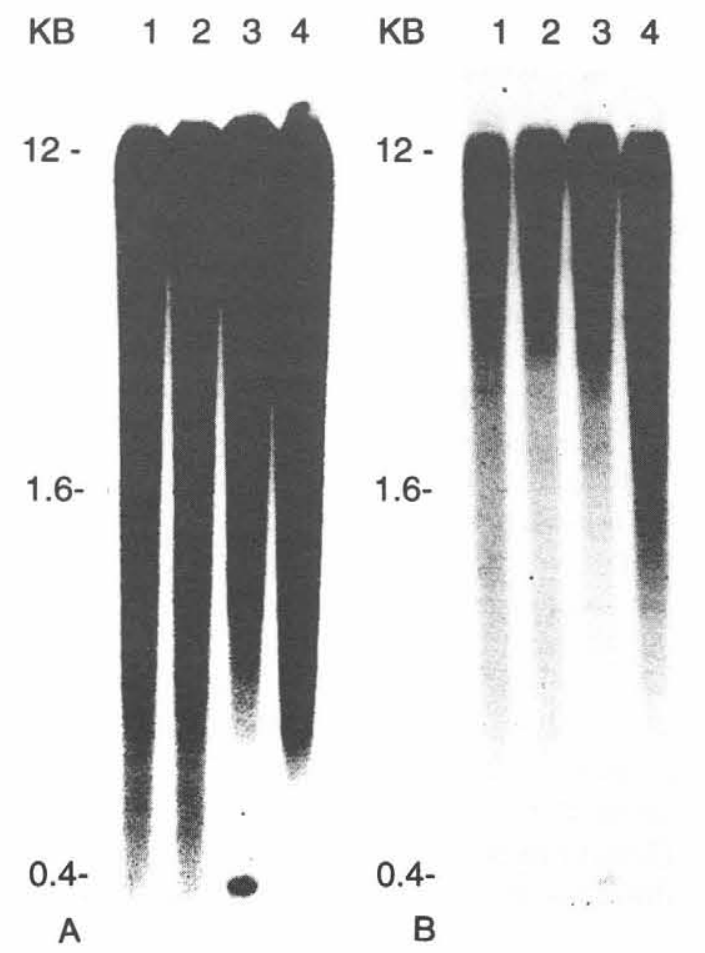

Figure 5. Genomic Southern blots of gypsy moth DNA probed with OPD-2generated marker DNA fragments. (a) and (B), identical blots probed with OPD-02 696 and OPD-02 591 respectively. Lanes 1 and 2 contain Asian moth DNA and lanes 3 and 4 contain North American moth DNA digested with EcoRI.

(C) 1996 Blackwell Science Ltd, Insect Molecular Biology 5: 81-91 three North American types. Similarly, the results of amplification of DNA from two backcross families were close to the expected ratios of 1:1 for the hybrid:Asian or North American parental type. The first set, offspring of an $F_{1}$ hybrid crossed with a North American moth, had nine hybrid and ten North American types, and the second set, from an $F_{1}$ hybrid crossed with an Asian moth had nine hybrids and eleven Asian types. The results indicate that the marker exists as a single-copy autosomal locus with co-dominant Mendelian inheritance.

\section{Characterization of locus copy number by genomic Southern blotting}

The OPD-02 $2_{696}$ Asian fragment and the OPD-02 591 North American fragments were both radioactively labelled and hybridized to blotted genomic gypsy moth DNA digested with EcoRI. The results are shown in Fig. 5. Both probes hybridize as smears, indicating

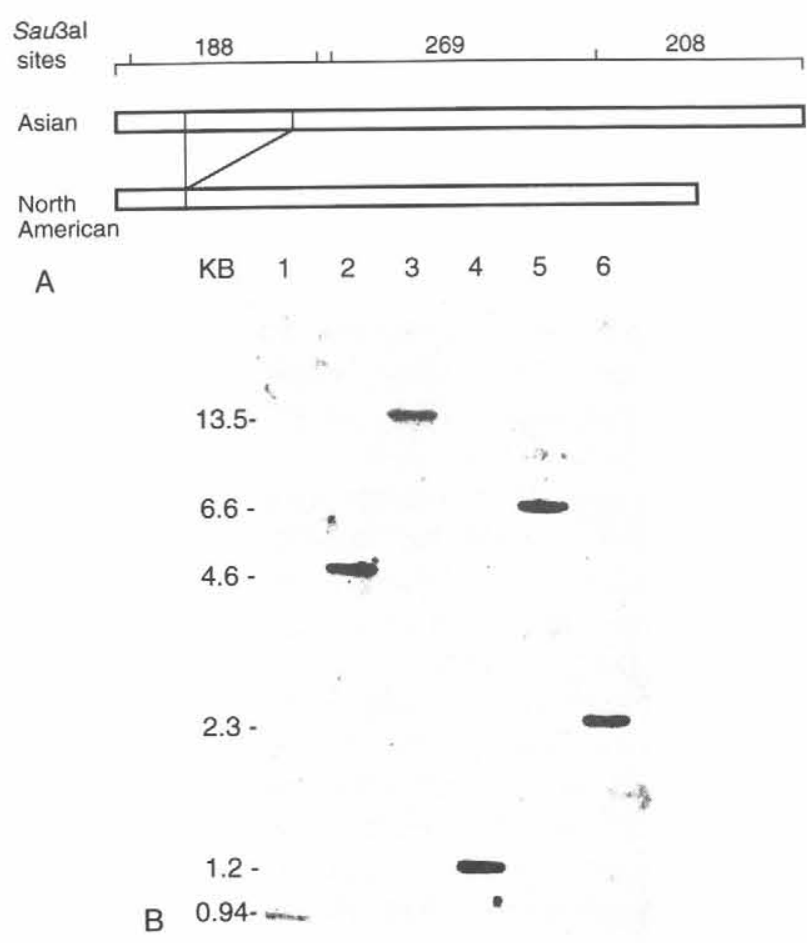

Figure 6. (A) Diagram of the location of the OPD-02 ${ }_{696} 269$ basepair SaLßal subfragment within the Asian and North American marker fragment sequences. Sizes of the larger Saしßal fragments are indicated above the line. The 208 basepair fragment ends at the EcoRI site in the cloning vector. The location of the insertion/deletion region differentiating the Asian and North American alleles is indicated below the line. (B). A genomic Southern blot of North American gypsy moth DNA probed with the 269 basepair SaL3al subfragment of OPD-02 696 . Lane 1, Accl; lane 2, Aval; lane 3, Bg/ll; lane 4; Clal; lane 5, HindIII; and lane 6, Ndel. Sizes of hybridizing bands are indicated. 
that the fragments contain repetitive DNA sequences. In addition, the repetitive sequence or sequences are not limited to the 105 basepair region found in the Asian but not the North American fragment.

Because the inheritance of the markers in $F_{2}$ and backcross hybrids suggests that the marker region being amplified is a single-copy locus, three SauBAI subfragments of the 696 basepair Asian fragment were also used to probe genomic blots to attempt to find a single-copy portion (Fig. 6A). Hybridization with the 188 and 208 basepair fragments generated smears (data not shown), but a 269 basepair region in the centre of the 696 basepair fragment hybridizes primarily as a single band when used to probe genomic DNA digested with six different restriction enzymes (Fig. $6 \mathrm{~B})$. This indicates that although the full-length OPD$02_{696}$ fragment contains repetitive DNA regions, a single-copy region also exists. The location and extent of the repetitive sequences within the marker region have not been characterized. However, the RAPDPCR and locus-specific primers may be binding in single-copy regions flanking the polymorphic portion (i.e. the 105 basepair insertion or deletion) of the marker.

\section{Discussion}

We developed a nuclear DNA marker, FS-1, that can be used to differentiate the Asian and North American strains of the gypsy moth. The marker exhibits an accuracy rate of $96 \%$ when tested on known North American moths and $100 \%$ when tested on moths originating in far eastern Asia. In addition, the marker will identify Asian/North American hybrid moths. This marker will be useful for identifying specimens in regions where recent introductions of Asian moths are suspected and for monitoring these regions following eradication efforts.

It is not known how many European moth individuals were released in Massachusetts in 1869, but it was probably a relatively small number. The bandsharing analysis indicates that the North American individuals are more genetically homogeneous $(0.16$ intra-strain distance) than the Asian population. Homogeneity within the North American population has also been seen using isozyme and mtDNA RFLP analyses (Harrison et al., 1983). Approximately as much variation exists within the Asian population $(0.26 \%$ distance $)$ as is seen between the Asians and North Americans ( $0.27 \%$ distance). Overall, however, the two strains are genetically very similar, contributing to the paucity of observed useful RAPD-PCR markers.
The FS-1 marker locus has been characterized to confirm that it is a chromosomal and not a mitochondrial marker. The inheritance pattern is that of an autosomal codominant single copy locus. Although the entire OPD- $02_{696}$ fragment contains a highly repetitive sequence or sequences, a 269 basepair subfragment hybridizes to a single band on a genomic blot, indicating that the polymorphic portion of the fragment may be linked to single copy sequences that bind the PCR primers. If the primers were amplifying dispersed repetitive sequences, and if the repeat units were segregating randomly, the $F_{2}$ and backcross hybrids would have a higher proportion of individuals typing as hybrids. It would also be unexpected that an insertion/deletion polymorphism could become completely fixed in most or all copies of a repetitive sequence in only one of two closely-related moth strains. In any case, the $F_{2}$ and backcross inheritance patterns indicate that the Asian and North American FS-1 marker forms each segregate as single units.

A disadvantage of RAPD-PCR is that slight changes in reaction conditions can lead to inconsistent results. Results using RAPD primers frequently differ between laboratories. In order to minimize variations due to technical artefacts of RAPD-PCR, we sequenced the diagnostic RAPD fragments and developed locus-specific primers. These primers amplified the expected bands in most individuals. In a few cases a hybrid pattern was detected with one primer set but not another. These cases were probably due to nucleotide polymorphisms at the primer binding site. Null results were rarely if ever seen in 'pure' North American or far east Asian samples, but non-detectable polymorphisms in these individuals would have been masked by the presence of a detectable allele. Analysis of more hybrid individuals should allow the selection of primers or mixtures of primers that will detect the majority of sequence variants.

The problem of identification of Asian introductions into North America has been complicated by the arrival of moths with Asian characteristics (female flight) on ships from Europe. This occurred in 1993 in Sunny Point, North Carolina (South, 1994; North Carolina Department of Agriculture, 1994), and also at military shipping ports in Washington in 1993 and 1994 (Wood, 1994). It is believed that Asian moths have been introduced into some regions in Europe in recent years (Graser et al., 1995) providing another route into North America. The FS-1 marker has been used to test DNA from moths collected at several European locations, including some where female flight has been observed and others where the moths appear to be of the European type. At all sites a mix of Asian, North American and hybrid marker forms are seen, with

(C) 1996 Blackwell Science Ltd, Insect Molecular Biology 5: 81-91 
proportions of each varying between sites (data not shown). The original European population may have contained both forms of the marker, but it will be very difficult to test this as it is almost impossible to confirm the existence of a pure European population now.

The occurrence of the so-called Asian form in North America may be a consequence of its presence in the original European moths released in Massachusetts in 1869. Alternatively, other undetected Asian or European introductions may have occurred since then. One population with a higher than usual occurrence of the FS-1 Asian form is in Ashtabula County, Ohio, approximately 20 miles from Lake Erie. In addition, analysis of mitochondrial markers has found elevated frequency of Asian types in Ashtabula Co., Ohio, as well as in Cleveland and Toledo, Ohio and Detroit, Michigan (Prasher \& Mastro, 1995). Overseas shipping on the Great Lakes may have carried Asian or European gypsy moths into this and other areas.

The accuracy rate for the marker in correctly identifying Asian samples is $100 \%$ for samples originating in far-eastern Russia (106 individuals), but moths with the North American form occur with greater frequency in central Russia (two of nine tested). Individuals from more areas need to be tested, but the FS-1 marker may be most useful in identifying Asian moths originating in far Eastern ports of Russia, Japan, and China.

The lack of clear genetic differentiation between Asian and North American gypsy moths combined with the variability within the Asian population will probably make it very difficult to find any single genetic marker that gives $100 \%$ accurate results. However, the FS-1 marker, in combination with the mitochondrial and other nuclear markers of similar accuracy, should allow statistically valid identification of suspect moth specimens.

\section{Experimental procedures}

\section{DNA samples}

Asian gypsy moth samples used in screening decanucleotide primers were collected in China (Beijing, Hubei, Liaoning and Shandong), Japan (Hokkaido, Kashiwada, Kukisaki, Namiki and Sakuragaoka), Russia (Mineralni, in Primor'ye Territory, and Bellyk, in Krasnoyarsk Territory) or were reared from egg masses collected from ships originating in Vladivostok, Russia. North American moths were collected from Massachusetts (Norfolk County), Michigan (Manistee, Newaygo, Oceana and Ottawa Counties), North Carolina (Currituck and Dare Counties), Ohio (Ashtabula County), Pennsylvania (Forbes State Forest) and West Virginia (Cooper's Rock State Forest). Hybrids were generated at the USDA Forest Service Quarantine Laboratory, Ansonia, Connecticut, from individuals of known geographic origin.

\section{Preparation of gypsy moth DNA}

The DNA from larvae or adult gypsy moths was prepared using a modification of the method of Ish-Horowicz et al. (1979). Tissue was homogenized using glass homogenizers in a grind buffer consisting of $10 \mathrm{~mm}$ Tris- $\mathrm{Cl} \mathrm{pH} \mathrm{7.5,60} \mathrm{mM} \mathrm{NaCl,}$ and $10 \mathrm{~mm}$ EDTA. An equal volume of post-grind buffer (200 $\mathrm{mm}$ Tris- $\mathrm{Cl} \mathrm{pH}$ 9.0, $30 \mathrm{~mm}$ EDTA and $2 \%$ sodium dodecyl sulfate) was added to the homogenate. Proteinase $\mathrm{K}$ was added to a final concentration of $200 \mu \mathrm{g} / \mathrm{ml}$ and the solution was incubated for $4-16 \mathrm{~h}$ at $50^{\circ} \mathrm{C}$. After the Proteinase $\mathrm{K}$ treatment, sodium acetate $(\mathrm{pH} 4.8)$ was added to a final concentration of $0.3 \mathrm{M}$. The solution was extracted with an equal volume of buffered phenol, then with an equal volume of chloroform/isoamyl alcohol (24/1). Two volumes of ethanol were added to precipitate the DNA. After at least $2 \mathrm{~h}$ at $-20^{\circ} \mathrm{C}$ the DNA was pelleted by centrifugation at $8000 \mathrm{~g}$ for $30 \mathrm{~min}$.

The DNA was resuspended in $200 \mu \mathrm{l}$ water and treated with $200 \mu \mathrm{g} / \mathrm{ml}$ RNAse $A$ for $2 \mathrm{~h}$ at $37^{\circ} \mathrm{C}$ in the presence of $50 \mathrm{~mm}$ Tris- $\mathrm{Cl} \mathrm{pH} 8.0$ and $10 \mathrm{mM} \mathrm{MgCl}_{2}$. The DNA was then extracted with phenol and chloroform and precipitated with ethanol in the presence of $0.3 \mathrm{M}$ sodium acetate. The DNA was resuspended in $200 \mu \mathrm{l}$ water.

The DNA prepared from larvae often required further purification for consistent amplification. The DNA solution was purified using an Elutip-D column following the manufacturer's instructions.

Crude preparation of DNA from eggs was done by crushing the egg with a disposable pipettor tip and incubating for $4 \mathrm{~h}$ at $56^{\circ} \mathrm{C}$ in $100 \mu \mathrm{l}$ of a buffer containing $10 \mathrm{~mm}$ Tris- $\mathrm{Cl} \mathrm{pH} \mathrm{8.0,0.1 \%}$ $\mathrm{NP} 40$, and $50 \mu \mathrm{g} / \mathrm{ml}$ proteinase $\mathrm{K}$. Following incubation the lysate was incubated at $80^{\circ} \mathrm{C}$ for $10 \mathrm{~min}$ to inactivate the proteinase K. A 1:10 or 1:100 dilution of the lysate was often necessary to reduce the concentration of inhibitory substances. DNA from small fragments punched out of wings with a capillary pipette were also prepared in the same way.

\section{RAPD-PCR methods}

RAPD-PCR amplifications were performed under two slightly different sets of conditions at two different laboratories. Operon 20-primer sets OPA, OPB, OPC and OPD were used at Delaware, Ohio in $25 \mu \mathrm{l}$ reactions containing $10 \mathrm{ng}$ DNA, $50 \mathrm{~mm}$ $\mathrm{KCl}, 10 \mathrm{~mm}$ Tris- $\mathrm{Cl}\left(\mathrm{pH} 9.0\right.$ at $\left.25^{\circ} \mathrm{C}\right), 0.1 \%$ Triton $\mathrm{X}-100,2.0 \mathrm{~mm}$ $\mathrm{MgCl}_{2}, 0.2 \mathrm{~mm}$ each dNTP, $0.2 \mu \mathrm{M}$ primer and 0.625 units Taq DNA polymerase (Boehringer Mannheim or Perkin Elmer). Reactions were topped with a drop of mineral oil. The samples were incubated in $0.5 \mathrm{ml}$ tubes in a Perkin Elmer thermal cycler for $2 \mathrm{~min}$ at $94^{\circ} \mathrm{C}$ (initial denaturation step) and then for forty-five cycles consisting of $94^{\circ} \mathrm{C}$ for $1 \mathrm{~min}, 36^{\circ} \mathrm{C}$ for 1 $\min$, and $72^{\circ} \mathrm{C}$ for $2 \mathrm{~min}$.

142 decanucleotide primers were screened at the Southern Institute of Forest Genetics, USDA Forest Service, Gulfport, Mississippi. The primers used were University of British Columbia numbers $102,103,108,111,114,116,119,122,123$, $129,132,133,135,146,153,155,159,167-169,171,181,184$, $186,190,193,195,198,200,202,203,209,210,213,219,222$, $225,242,248,254,256,258,264,266-271,285,288,295-297$. $299-301,308,315-320,322,324,327,330,333,336,337,348$, $352,357,360,362,367,370,375,376,381,389,396,399,402$, $403,423,424,427,429,452,460,471,479,483,485,493,499$, $504-507,509,510,517,519,530-533,536,550,551,554,561$, $562,564,566,570,578-580,582,586,587,589,590,599,600$, 
$614,618,624,625,631,633,638,645,654,660,679,686$ and 695 . The reactions were performed in 96-well microtitre plates on a MJR thermal cycler. The $16 \mu \mathrm{l}$ reactions contained $10 \mathrm{~mm}$ Tris$\mathrm{Cl} \mathrm{pH} \mathrm{8.3,} 1.5 \mathrm{~mm} \mathrm{MgCl}_{2}, 50 \mathrm{~mm} \mathrm{KCl}, 0.01 \%$ gelatin, $0.2 \mathrm{~mm}$ each dNTP, $3.125 \mathrm{ng}$ DNA, $0.3125 \mu \mathrm{m}$ primer, and 1 unit Boehringer Mannheim Taq DNA polymerase. The samples were incubated at $95^{\circ} \mathrm{C}$ for $5 \mathrm{~s}$ and $1: 55 \mathrm{~min}$ at $92^{\circ} \mathrm{C}$ (initial denaturation steps) and then for forty-four cycles consisting of $95^{\circ} \mathrm{C}$ for $5 \mathrm{~s}, 92^{\circ} \mathrm{C}$ for $55 \mathrm{~s}, 35^{\circ} \mathrm{C}$ for $1 \mathrm{~min}$, and $72^{\circ} \mathrm{C}$ for $2 \mathrm{~min}$. Following these cycles the samples were incubated at $72^{\circ} \mathrm{C}$ for $7 \mathrm{~min}$ and then held at $4^{\circ} \mathrm{C}$.

Reaction results were analysed by electrophoresis in $1.2 \%$ agarose gels using Tris-borate EDTA buffer followed by ethidium bromide staining of the DNA.

\section{Screening of RAPD PCR primers}

Initially eighty Operon decanucleotide primers (sets OPA to OPD) were used to amplify three to five DNA samples from each geographic location. 142 University of British Columbia primers were used to test fifteen Asian and nine North American samples. In many cases the results obtained in Gulfport, Mississippi, could not be reproduced in the Delaware, Ohio laboratory, although attempts were made to match the reaction components exactly. When reproducibility was good, any primer which appeared to amplify a diagnostic fragment was tested on increasing numbers of moths until up to fifty individuals of each strain had been analysed. The sequence of primer OPD-02 is 5' GGACCCAACC 3'.

\section{Band-sharing analysis}

Twenty primers (University of British Columbia primers 108, $111,114,116,119,122,123,129,132,133,153,155,159,167$. $168,169,171,181,186$ and 190) were selected for a bandsharing analysis of fifteen Asian and nine North American moth individuals. The fifteen Asian moths were from egg masses collected on ships originating in Russia found entering ports in the Pacific Northwest. The North American moths included two from Massachusetts, two from Michigan, one from Ohio, two from the New Jersey Standard Laboratory Strain, one from Pennsylvania, and one from West Virginia.

322 strong and moderate bands were scored and the results analysed using the 'distance matrix' function of PAUP 3.1.1 (Swofford, 1993). This function performs pairwise calculations of the number of shared bands divided by the total number of bands. Pairwise distance values were averaged within Asians, between Asians and North Americans, and within North Americans.

\section{Characterization of the diagnostic fragments amplified by primer OPD02}

Amplified DNA from a representative gel was blotted onto Duralon hybridization membrane according to the manufacturer's instructions. The Asian (OPD-02 700 ) and North American (OPD-02 $2_{590}$ ) diagnostic fragments were gel-purified from low-melting-point agarose and cloned using the TA cloning kit (Invitrogen). Multiple fragments differing slightly in size were cloned, so gel-purified plasmid insert DNA was radioactively labelled using the Gibco BRL Nick Translation System and hybridized to the RAPD PCR gel blot to identify the correct clones. Once the correct clones were identified, double- stranded plasmid DNA was sequenced using the Sequenase (United States Biochemical Co.) sequencing kit.

\section{Genomic blot}

$20 \mu \mathrm{g}$ of genomic DNA were digested with restriction enzymes and run on $0.8 \%$ agarose gels. To ensure that the digestion was complete, a $20 \%$ portion of the restriction enzyme reaction mix was removed to a separate tube and $1 \mu \mathrm{g}$ of lambda phage DNA was added. The lambda DNA was allowed to digest under the same conditions as the remainder of the genomic DNA. The lambda reaction was checked on a separate gel for completeness of digestion before the remainder of the genomic DNA was used for blotting. After electrophoresis the gel was blotted onto Duralon hybridization membrane following the manufacturer's directions.

The OPD- $02_{696}$ and OPD- $02_{591}$ fragments and the OPD-02 696 SaLßal 188 and 208 basepair subfragments were radioactively labelled using the Gibco BRL Nick Translation System. The 269 basepair SaLBAI subfragment labelled poorly using the kit so instead it was self-ligated and then labelled using specific primer L346 and random primer labelling conditions. The $50 \mu \mathrm{l}$ labelling reaction contained $50 \mathrm{~mm}$ Tris- $\mathrm{Cl} \mathrm{pH} \mathrm{6.8,5} \mathrm{mM} \mathrm{MgCl}_{2}$, $10 \mathrm{~mm}$ betamercaptoethanol, $150 \mu \mathrm{g} / \mathrm{ml}$ primer D2L346, $0.2 \mathrm{~mm}$ each dATP, dGTP, and dTTP, $50 \mu \mathrm{Ci}^{32} \mathrm{P} \mathrm{dCTP}$, and 12 units Klenow fragment of $E$. coli DNA polymerase I. The DNA and primer were annealed by heating to $90^{\circ} \mathrm{C}$ for 2 min and cooling to $20^{\circ} \mathrm{C}$ over $20 \mathrm{~min}$. The remaining reagents were added and the reaction was incubated at $37^{\circ} \mathrm{C}$ for $1 \mathrm{~h}$. Unincorporated dNTPs were removed using a Sephadex G-50 spun column.

\section{Selection of locus-specific diagnostic primers}

Seventeen to twenty base locus-specific primer pairs were selected in non-polymorphic regions of the diagnostic fragments, based on comparison of the Asian and North American sequences. The OLIGO Primer Analysis software package (National Biosciences, Inc.) was used to analyse the selected primer sequences for possible internal secondary structure or primer-primer interactions.

\section{DNA amplification using locus-specific primers}

The locus-specific primer sequences are as follows: U22: TATGGTATAGSGGATGGTGG $3^{\prime}$, L346: $5^{\prime}$ ATTTGTTCTGTTGTTTGRGG 3', U29: 5' TAGSGGATGGTGGGTGTCGT 3', L374: 5' TTCCGGAGAGGACATCGACG 3 ,', U33: 5' GGATGGTGGGTGTCGTT 3', L325: 5' GGTTGGTTGATGATTAGATG 3'. Amplifications were performed in $25 \mu$ reactions containing 10 ng DNA, $50 \mathrm{~mm} \mathrm{KCl}, 10 \mathrm{~mm}$ Tris- $\mathrm{Cl}\left(\mathrm{pH} 9.0\right.$ at $\left.25^{\circ} \mathrm{C}\right), 0.1 \%$ Triton $\mathrm{X}-100,1.5 \mathrm{~mm} \mathrm{MgCl}, 0.2 \mathrm{~mm}$ each dNTP, $0.2 \mu \mathrm{m}$ primer and 0.3 units Taq DNA polymerase. Reactions were most successful when hot start PCR was used. In this case the lower reaction mix consisted of primers, dNTPs and water, while the upper reaction mix included the $10 \times$ buffer, DNA, and Taq polymerase. The samples were incubated in a thermal cycler for $2 \mathrm{~min}$ at $94^{\circ} \mathrm{C}$ (initial denaturation step) and then for 45 cycles consisting of $94^{\circ} \mathrm{C}$ for $1 \mathrm{~min}, 49^{\circ} \mathrm{C}$ for $1 \mathrm{~min}$, and $72^{\circ} \mathrm{C}$ for $1 \mathrm{~min}$.

Reaction results were analysed by electrophoresis in $2 \%$ agarose gels using Tris-borate EDTA buffer followed by ethidium bromide staining of the DNA. 


\section{GenBank accession numbers}

The sequences reported here have the GenBank accession numbers LDFS1A01U37125, LDFS1A78U-37126, LDFS1A 97U37127, LDFS1N06U37128, LDFS1N-78U37129 and LDFS1N97U37130.

\section{Acknowledgements}

We thank Melody Keena for Asian, European and North American specimens and for generation of hybrids and backcross samples. We also thank Bonita Baldwin, Alan Baumgard, Hermann Bogenschutz, Lee Humble, Vic Mastro, Mary Smallsreed and Regis Young for additional samples. We are very grateful to Warren Nance for screening large numbers of RAPDPCR primers.

\section{References}

Bogdanowicz, S.M., Wallner, W.E., Bell, J., O'Dell, T.M. and Harrison, R.G. (1993) Asian gypsy moths (Lepidoptera: Lymantriidae) in North America: evidence from molecular data. Ann Entomol Soc Am 86: 710-715.

Clarke, C. and Ford, E.B. (1980) Intersexuality in Lymantria dispar (L.): a reassessment. Proc $R$ Soc Lond B 206: 381-394.

Edwards, O.R. and Hoy, M.A. (1993) Polymorphism in two parasitoids detected using random amplified polymorphic DNA polymerase chain reaction. Biol Contro/3: 243-257.

Favia, G., Dimopolous, G. and Louis, C. (1994) Analysis of the Anopheles gambiae genome using RAPD markers. Insect Molec Bio/ 3: 149-157.

Folkertsma, R.T., Rouppe van der Voort, N.A.M., van Gent-Pelzer, M.P.E., de Groot, K.E., (Reineke) van den Bos, W.J., Schots, A., Bakker, J. and Gommers, F.J. (1994) Inter- and intraspecific variation between populations of Globodera rostochiensis and G. pallida revealed by random amplified polymorphic DNA. Genetics 84: 807-811.

Forbush, E.H. and Fernald, C.H. (1896) The Gypsy Moth. Boston, Wright and Potter Printing Co., State Printers.

Gawel, N.J. and Bartlett, A.C. (1993) Characterization of differences between whiteflies using RAPD-PCR. Insect Molec Bio/2: 33-38.

Gibbons, A. (1992) Asian gypsy moth jumps ship to United States. Science 255: 526.

Goldschmidt, R. (1940) The Material Basis of Evolution. Yale University Press, New Haven.

Graser, V.E., Wulf, A. and Burgermeister, W. (1995) Intraspecific variation of gypsy moth (Lymantria dispar) revealed by RAPDPCR. Nachrichtenbl Deut Pflanzenschutzd 47: 25-27.

Harrison, R.G., Wintermeyer, S.F. and O'Dell, T.M. (1983) Patterns of genetic variation within and among gypsy moths, Lymantria dispar (Lepidoptera: Lymantriidae), populations. Ann Entomol Soc Am 76: 652-656.

Ish-Horowicz, D., Pinchin, S.M., Schedl, P., Artavanis-Tsakoncis, S. and Mirault, M. (1979) Genetic and molecular analysis of the $87 \mathrm{~A} 7$ and $87 \mathrm{C} 1$ heat-inducible loci of Drosophila melanogaster. Cell 18: 1351-1358.
Keena, M.A. (1994a) Genetics and biology of Asian gypsy moth and its hybrids. US Department of Agriculture Interagency Gypsy Moth Research Forum, General Technical Report NE-188, p. 32.

Keena, M.A. (1994b) Identification of Gypsy Moth Larval Color Forms. US Department of Agriculture Forest Service Leaflet NE/NA-INF-123-94.

Krider, H.M. and Shields, K.S. (1994) Developmental genetics of Lymantria dispar. US Dept of Agriculture Interagency Gypsy Moth Research Forum, General Technical Report NE-188, pp. 33-34.

Mudge, A.D., Hilburn, D.J. and Johnson, K.J.R. (1994) Gypsy moth detection and eradication programs in Oregon. Proceedings of the 1994 Annual Gypsy Moth Review, pp. 319-324.

North Carolina Department of Agriculture (1994) North Carolina gypsy moth program: 1994 overview. Proceedings of the 1994 Annual Gypsy Moth Review, pp. 305-315.

Paran, I. and Michelmore R.W., (1993) Development of reliable PCR-based markers linked to downy mildew resistance in lettuce. Theor App/ Genet 85: 985-993.

Prasher, D. and Mastro, V. (1995) Genotype analysis of 1994 port specimens. Proceedings of the 1994 Annual Gypsy Moth Review (Hilburn, D.J., Johnson, K.J.R. and Mudge, A.D., eds). pp. 61-63.

Puterka, G.J., Black, W.C., IV, Steiner, W.M. and Burton, R.L. (1993) Genetic variation and phylogenetic relationships among worldwide collections of the Russian wheat aphid, Diuraphis noxia (Mordvilko), inferred from allozyme and RAPD-PCR markers. Heredity 70: 604-618.

Roehrdanz, R.L., Reed, D.K. and Burton, R.L. (1993) Use of polymerase chain reaction and arbitrary primers to distinguish laboratory-raised colonies of parasitic hymenoptera. Biol Contro/3: 199-206.

Scieux, C., Grimont, F., Regnault, B., Bianchi, A., Kowalski, S. and Grimont, P.A.D. (1993) Molecular typing of Chlamydia trachomatis by random amplification of polymorphic DNA. Res Microbiol 144: 395-404.

South, M.D. (1994) North Carolina update. Gypsy Moth News 34: 12.

Swofford, D.L. (1993) PAUP: Phylogenetic Analysis Using Parsimony, Version 3.1.1. Illinois Natural History Survey, University of Illinois, Champaign.

US Department of Agriculture, Forest Service (1995) Gypsy Moth Management in the United States: a Cooperative Approach. Draft Environmental Impact Statement, pp. 1-6.

Wallner, W.E., Grinberg, P.S. and Keena, M.A. (1994) Female flight: evaluation of Asian gypsy moth and its hybrids. 1994 US Department of Agriculture Interagency Gypsy Moth Research Forum, General Technical Report NE-188, p. 89.

Wallner, W.E., Grinberg, P.S. and Walton, G.S. (1995) Differentiation between gypsy moth (Lepidoptera: Lymantriidae) populations by spectral color discrimination of head capsules. Environ Entomol 23: 659-664.

Williams, J.G.K., Kubelik, A.R., Livak, K.J., Rafalski, J.A. and Tingey, S.V. (1991) DNA polymorphisms amplified by arbitrary primers are useful as genetic markers. Nucleic Acids Res 18: $6531-6535$.

Wood, J. (1994) Washington State Department of Agriculture, Plant Services Division. 1994 gypsy moth program summary report. Proceedings of the 1994 Annual Gypsy Moth Review, pp. 334 342. 